\title{
CHARACTERISTICS OF BODY LOAD IN PHYSICAL TRAINING FOR FOOTBALL PLAYERS
}

CARACTERISTIICAS DA CARGA CORPORAL DO TREINAMENTO FISICO EM JOGADORES DE FUTEBOL

CARACTERISTICAS DE LA CARGA CORPORAL DEL ENTRENAMIENTO FÍSICO EN JUGADORES DE FÚTBOL

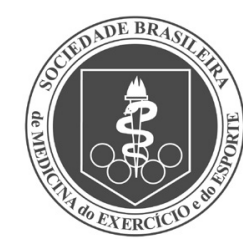

Original Article ARTIGO ORIGINAL Artículo Original
Jun Zhang1 (D)

(Physical Education Professional) Yanwen Lu' (D)

(Physical Education Professional)

Dong Liang ${ }^{1}$ (D)

(Physical Education Professional)

Liu Han' (D)

(Physical Education Professional)

Xiaodong Zhang' ${ }^{1}$ (D)

(Physical Education Professional)

Bo Wang ${ }^{3}$ (D)

(Physical Education Professional)

1. Guangzhou Xinhua University, Dongguan, Guangdong, China.

2. Medical College of Jiaying

University, Meizhou, Guangdong, China.

3. Football (Industry) College of Jiaying University, Meizhou, Guangdong, China.

\section{Correspondence:}

Jun Zhang

Dongguan, Guangdong, China. 523133.junfang625@163.com

\begin{abstract}
Introduction: Overtraining in football is caused by an imbalance between body load, stress, and recovery. High-volume non-scientific physical training and continuous high-intensity football matches are often the main reasons for the overtraining of athletes. Objective: This article explores the characteristics of the changes in physical function of football players during a complete training cycle. Methods: We use experimental methods to analyze the changes in the physical load characteristics of football players during high-intensity training. Results: Creatine kinase, urea nitrogen, and oxygen transport indicators did not change significantly during football training. Testosterone and cortisol will gradually increase with an increase of exercise load. Conclusion: In football training, we need to reasonably arrange the total exercise volume, exercise intensity, and exercise interval time of the athletes according to the trainer's physical adaptability and athletic ability, supplemented with nutrition and enthusiasm recovery measures. These methods can improve or enhance the physical function of football players. Level of evidence Il; Therapeutic studies - investigation of treatment results.
\end{abstract}

Keywords: Football; Athletes; Exercises; Human physical training.

\section{RESUMO}

Introdução: O treino excessivo no futebol é causado por um desequilíbrio entre a carga corporal, o estresse e a recuperação. O treinamento físico não científico de alto volume e as partidas contínuas de futebol de alta intensidade costumam ser as principais razões do treinamento excessivo dos atletas. Objetivo: Este artigo explora as características das mudanças de função física dos jogadores de futebol durante um ciclo completo de treinamento. Métodos: Usamos métodos experimentais para analisar as mudanças nas características de carga física de jogadores de futebol durante o treinamento de alta intensidade. Resultados: Os indicadores de creatina quinase, nitrogênio da ureia sanguínea e transporte de oxigênio não significativamente durante o treinamento de futebol. A testosterona e o cortisol aumentam gradualmente com o aumento da carga dos exercícios. Conclusões: No treinamento de futebol, precisamos organizar razoavelmente o volume total do exercício, sua intensidade e o tempo de intervalo dos atletas, de acordo com a adaptabilidade física e habilidade atlética do treinador, e com medidas de recuperação nutricional e de entusiasmo. Esses métodos podem melhorar ou aprimorar a função física dos jogadores de futebol. Nível de Evidência ll; Estudos terapêuticos - Investigação dos resultados do tratamento.

Descritores: Futebol; Atletas; Exercício; Condicionamento físico humano.

\section{RESUMEN}

Introducción: El sobreentrenamiento en el fútbol es causado por un desequilibrio entre la carga corporal, el estrés y la recuperación. El entrenamiento físico de alto volumen no científico y los partidos de fútbol continuos de alta intensidad suelen ser las principales razones del sobreentrenamiento de los atletas. Objetivo: Este artículo explora las características de los cambios en la función física de los jugadores de fútbol durante un ciclo completo de entrenamiento. Métodos: Utilizamos métodos experimentales para analizar los cambios en las características de la carga física de los jugadores de fútbol durante el entrenamiento de alta intensidad. Resultados: Los indicadores de creatina quinasa, nitrógeno ureico en la sangre y transporte de oxígeno no fueron significativos durante el entrenamiento. La testosterona y el cortisol aumentan gradualmente con el aumento de la carga de ejercicios. Conclusiones: En el entrenamiento de fútbol, se debe organizar razonablemente el volumen total de ejercicios, la intensidad y el tiempo de intervalo de los atletas en función del acondicionamiento físico y la capacidad atlética del entrenador, y con medidas de recuperación nutricional y de entusiasmo. Estos métodos pueden mejorar o potenciar la función física de los jugadores de fútbol. Nivel de Evidencia ll; Estudios terapéuticos - Investigación de los resultados del tratamiento.

Descriptores: Fútbol; Atletas; Ejercicio; Acondicionamiento físico humano. 


\section{INTRODUCTION}

The further development of the level of football makes the competition increasingly fierce. The demands on athletes' physical fitness, skills and tactics, and psychology will increase accordingly.' Football is a group sports event, which has higher requirements for aerobic and anaerobic metabolism. Football is a mixed-oxygen sport, which requires greater anaerobic capacity. Therefore, athletes are required to have the higher anaerobic capacity and aerobic capacity.

How to effectively supervise the functional status of football players during training has always been a concern for coaches and scientific researchers. This article intends to monitor the physical function of athletes during the high-intensity training week during the training of the national football team. We understand the changes in the athlete's body function and analyze the impact of the training process on the athlete's body. ${ }^{2}$ This can prevent sports injuries and overtrain. At the same time, this research can also provide references for future training and competitions.

\section{METHOD}

\section{Research object}

There are 30 athletes from the youth football training team. The average age is $18.68 \pm 2.09$ years, the average height is $177.55 \pm 8.54 \mathrm{~cm}$, and the average weight is $73.02 \pm 14.47 \mathrm{~kg}$. The average training period is $6.14 \pm 2.24$ years.

\section{Research methods}

\section{Blood sample collection and processing}

We sample athletes in the early morning before (Monday), mid (Thursday), and after (Monday after recovery) of the high-intensity basic training week during the normal training period. ${ }^{3}$ All subjects took $200 \mu \mathrm{l}$ of peripheral blood from the ring finger under a quiet fasting state, centrifuged for $10 \mathrm{~min}$, and measured the index. The indoor temperature is $17-23^{\circ} \mathrm{C}$ and the relative humidity is $40 \%-55 \%$.

\section{Monitoring indicators and test methods}

Creatine kinase (CK) was determined by the $\mathrm{N}$-acetylcysteine method. Nanjing Jiancheng Institute of Biotechnology provided the creatine kinase kit. Urea Nitrogen (BUN) is determined by the micro-colorimetric method. Nanjing Jiancheng Institute of Biotechnology provided the urea nitrogen kit. Testosterone ( $T$ ) is determined by an enzyme-linked immunosorbent assay with magnetic particle separation. The Nanjing Jiancheng Institute of Biotechnology provided the testosterone kit. Cortisol (C) is measured by enzyme-linked immunosorbent assay with magnetic particle separation. Nanjing Jiancheng Institute of Biotechnology provided the cortisol kit.

\section{Statistical methods}

All data were analyzed and processed by SPSS11.5 software. The experimental data are expressed as mean \pm standard deviation. Significant comparisons between groups were performed by paired t-test.

Optimization of the relationship between football training and sports injuries

$P w n$ represents the type of sports injury. wn represents the nature of the athlete's sports injury. ${ }^{4}$ Then use the following formula to calculate the relationship between the nature, location, and sports events of different sports injuries in high-intensity football training

$$
Q_{r}=\frac{y_{i} \cdot y_{i} \varphi\left(x_{j}\right)}{\alpha_{i}} \times \frac{K\left(x, x_{i}\right)}{\sin \cdot p_{w n}}+b
$$

$y_{i}$ represents the sports injury site of the athlete in high-intensity football training. $\varphi$ represents the general law of sports injuries in different events. $x_{j}$ represents the athlete's training years. $b$ represents the key joints that are injured during the training process. $K\left(x, x_{i}\right)$ represents the proportion of the number of people injured in each event in high-intensity football training. $r$ represents the cumulative number of injuries of athletes in high-intensity football training. $Z$ represents the joints that athletes are vulnerable to injury during high-intensity football training. $B^{*}$ represents the athlete's exercise tolerance in all stages of high-intensity football training. $q$ * represents the athlete's maximum metabolic equivalent before and after sports training. ${ }^{5}$ We make statistics on the parts and types of athletes that are prone to injury during high-intensity football training

$$
Y_{l}^{n}=\frac{\left[h_{k}\left(x_{i}\right) \cdot g_{l}\left(x_{i}\right)\right.}{T_{\text {Start }} \cdot T_{\text {end }}} \cdot \frac{\varphi_{\text {crit }}}{Q_{(r)}}
$$

$h_{k}\left(x_{i}\right)$ represents the type of factor that caused the damage. $g_{l}\left(x_{i}\right)$ represents the percentage of factors that cause injuries in high-intensity football training. $T_{\text {Start }}$ represents various joints that are prone to sports injuries. $T_{\text {end }}$ represents the joint part with the highest proportion among vulnerable parts. ${ }^{6}$ Use the following formula to construct a classifier for the main factors of athletes' injury based on least squares support vector machine

$$
\max Z_{n}=p_{i} x_{i} \cdot \frac{\left(i n-p_{i j}\right)}{(y(\chi) * \gamma)} \cdot \delta M_{\psi}^{n}
$$

$p_{i} x_{i}$ represents the injury probability of waist, knee, elbow joint, thigh, shoulder joint, ankle, wrist, and other parts in high-intensity football training. $p_{i j}$ represents the probability of strains, sprains, bruises, and chronic strain in high-intensity football training. $\gamma$ represents the amount of high-intensity track and field training exercise. $\delta$ represents that the athlete has suffered different degrees of different types of injuries during the recent training.

\section{RESULTS}

The activity of serum creatine kinase (CK) of young men's football team athletes in the middle of the high-intensity training week was $506.72 \pm 334.45 \mathrm{IU} / \mathrm{L}$, which was significantly higher than that of the pre- and post-training period $(P<0.01)$. The concentration of serum urea nitrogen (BUN) in the middle of the high-intensity training week was $18.21 \pm 3.74 \mathrm{mg} / \mathrm{dl}$, which was significantly higher than before and after training $(P<0.05)$. There was no significant change in testosterone $(T)$ concentration before and after high-intensity training. The concentration of cortisol $(\mathrm{Cn})$ has a rising trend, but there is no significant difference $(P>0.05)$. The $T / C$ ratio showed a downward trend during the training process, and the latter period of high-intensity training was significantly lower than that of the pre-training period $(P<0.05)$ (Table 1).

Table 1. Changes of various indicators during the week of heavy exercise training (mean \pm s).

\begin{tabular}{c|c|c|c}
\hline Index & $\begin{array}{c}\text { The early stage of } \\
\text { high-intensity training }\end{array}$ & $\begin{array}{c}\text { Mid-intensity } \\
\text { training }\end{array}$ & $\begin{array}{c}\text { Late-stage of high- } \\
\text { intensity training }\end{array}$ \\
\hline $\mathrm{CK}(\mathrm{IU} / \mathrm{L})$ & $185.17 \pm 93.86$ & $506.72 \pm 334.45$ & $195.86 \pm 63.70$ \\
\hline $\mathrm{BUN}(\mathrm{mg} / \mathrm{dl})$ & $15.62 \pm 3.41$ & $18.21 \pm 3.74$ & $15.14 \pm 3.44$ \\
\hline $\mathrm{T}(\mathrm{ng} / \mathrm{dl})$ & $615.50 \pm 177.04$ & $627.00 \pm 235.68$ & $557.29 \pm 111.30$ \\
\hline $\mathrm{C}(\mathrm{mg} / \mathrm{l})$ & $203.44 \pm 90.49$ & $218.39 \pm 34.35$ & $223.57 \pm 50.74$ \\
\hline $\mathrm{T} / \mathrm{C}$ & $3.40 \pm 1.23$ & $2.86 \pm 0.83$ & $2.66 \pm 1.01$ \\
\hline
\end{tabular}




\section{DISCUSSION}

\section{Changes in serum CK and physical function status of athletes during the week of high-intensity training}

Strength quality is one of the important qualities of football players. It is the key quality for completing technical moves and effectively hitting opponents. Therefore, muscle strength training must be carried out reasonably and effectively in football training. ${ }^{8}$ The intensity control of strength training is the key to strength training. The serum creatine kinase concentration is one of the sensitive indicators to assess the intensity of strength training. Creatine kinase (CK), also known as creatine phosphate kinase, is abundant in skeletal muscle. It is one of the key enzymes of skeletal muscle energy metabolism. Its main role is to catalyze the reversible transfer of high-energy phosphate bonds between adenosine triphosphate and creatine phosphate.

Under normal circumstances, the structure of muscle cells is intact. It functions normally, which makes CK rarely penetrate the cell membrane, so the activity of $\mathrm{CK}$ in the serum is very low. ${ }^{9}$ After intensive exercise, CK activity increased by 4 times compared with the quiet value, which shows that CK activity increased significantly only after reaching a certain exercise intensity. Serum CK is more sensitive to intensity than to exercise. It can be seen that the increase of serum CK is not only related to exercise time but also related to exercise intensity.

It can be seen from Table 1 that the activity of serum creatine kinase in the middle of the training week is 506.72 $\pm 334.45 \mathrm{IU} / \mathrm{L}$, which is very significantly higher than the $185.17 \pm 93.86 \mathrm{IU} / \mathrm{L}$ in the pre-training period $(P<0.01)$. The serum CK of football players increased significantly after $3 \mathrm{~d}$ intensity training $(P<0.01)$. This shows that the muscle response to training stimulation is obvious. After a full day of active recovery on Sunday, the serum CK value returned to the pre-training level. This reflects the adaptability of athletes' muscle cells to sports training. The results showed that this high-intensity training program did not cause exercise-induced skeletal muscle damage.

\section{Changes in serum BUN and physical function status of ath- letes during the week of high-intensity training}

It can be seen from Table 1 that the serum BUN concentration in the pre-week training period is $15.62 \pm 3.41 \mathrm{mg} / \mathrm{dl}$. It increased significantly in the early morning of mid-training and reached $18.21 \pm 3.74 \mathrm{mg} / \mathrm{dl}(P<0.01)$. After recovery and adjustment, it reached $15.14 \pm 3.44 \mathrm{mg} / \mathrm{dl}$. The serum BUN returned to the level before the week of training.

Blood urea is the metabolic product of amino groups in protein and amino acid molecules released into the blood after being synthesized by the ornithine cycle in liver cells. Under normal physiological conditions, the production and elimination of blood urea are in equilibrium, and the blood urea level remains relatively stable. High-volume training or muscle energy balance will increase the blood urea content significantly. If the amount of exercise is acceptable to the athlete, the urea nitrogen will return to the normal level or a little lower than the original level the next day. If the amount of exercise is too large and exceeds the athlete's ability to bear, the urea nitrogen stays at a high level the next morning. Therefore, urea nitrogen is often used as an index to assess athletes' degree of physical fatigue and load.

\section{The impact of high-intensity training on the endocrine hor- mones of athletes}

Testosterone is the most active androgen in the body. It is a type of steroid hormone-containing 9 carbon atoms. This hormone promotes an important hormone for the body's anabolism and is regulated by the hypothalamic-pituitary-gonadal axis. The increase of serum T level under suitable exercise stimulation contributes to the body's anabolism after exercise. Long-term exercise will reduce the serum $T$ concentration and the longer the exercise duration. The greater the exercise load, the more obvious the decrease of serum T. Cortisol (C) is an important stress hormone in the body, which promotes the body's catabolism. This hormone plays an important role in material energy metabolism during heavy exercise training. Exercise for a short period with low or high intensity, but with a long interval, and serum C drops or does not change immediately after exercise. When the exercise load is large, serum $C$ still maintains a high value the next morning after exercise. However, some scholars believe that the change of $C$ value is short-lived and recovers quickly. Under certain circumstances, the concentration of serum $\mathrm{C}$ reflects the protein breakdown in athletes and the degree of response to exercise load.

This study found that high-intensity training serum $T$ concentration did not change significantly before and after training. The concentration of serum $C$ gradually decreased with the training, but there was no significant difference $(P>0.05)$. It can be seen that the $T$ and $C$ indicators of the high-intensity training week during this training period cannot clearly and timely reflect the physical function status of male football players. The T/C ratio showed a downward trend during the training process, and the latter period of high-intensity training was significantly lower than that of the pre-training period $(P>0.05)$. It is suggested that hormone indicators are not sensitive to indicators such as CK and BUN in the training monitoring process, so we can appropriately reduce the test density in the usual monitoring process.

\section{CONCLUSION}

Serum CK and BUN gradually increased with training and recovered to the pre-training level after active recovery and adjustment. The changes of blood testosterone, and cortisol to exercise load were not significant. The $\mathrm{T} / \mathrm{C}$ ratio showed a downward trend during the training process, and the latter period of high-intensity training was significantly lower than that of the pre-training period $(P>0.05)$. Among them, creatine kinase changed the most. It is the most sensitive to the degree of muscle fatigue. We need to reasonably arrange the total amount of exercise, exercise intensity, and exercise interval time in the training process. According to the specific situation of the trainer's physical adaptability and athletic ability, supplemented with nutrition and enthusiasm recovery measures. This can improve or enhance the physical function of the athlete.

All authors declare no potential conflict of interest related to this article

AUTHORS' CONTRIBUTIONS: The author made significant contributions to this manuscript. Biqing Chen: writing and performing surgeries; data analysis and performing surgeries; article review and intellectual concept of the article.

\section{REFERENCES}

1. Kostiukevych VM. Model indicators of collective interactions of highly qualified football players during the game. Health, Sport, Rehabili. 2019;5(4):33-40.

2. Bujalance-Moreno $P$, Latorre-Román PA, Ramírez-Campillo R, Martínez-Amat A, García-Pinillos F. The inclusion of wildcard players during small-sided games causes alterations on players' workload. Isokinet Exerc Sci. 2021;29(1):101-10.

3. Wiig $\mathrm{H}$, Andersen TE, Luteberget $\mathrm{LS}$, Spencer $\mathrm{M}$. Individual response to external training load in elite football players. Int J Sports Physiol Perform. 2020;15(5):696-704.

4. O'Keeffe S, O'Connor S, Ní Chéilleachair N. Are internal load measures associated with injuries in male adolescent Gaelic football players?. Eur J Sport Sci. 2020;20(2):249-60.

5. Wang A, Healy J, Hyett N, Berthelot G, Okholm Kryger K. A systematic review on methodological variation in acute: chronic workload research in elite male football players. Sci Med Footb. 2021;5(1):18-34
6. Lathlean TJ, Gastin PB, Newstead SV, Finch CF. Absolute and relative load and injury in elite junior Australian football players over 1 season. Int J Sports Physiol Perform. 2019;15(4):511-9.

7. Gamonales JM, Muñoz Jiménez J, Mancha-Triguero D, Ibáñez SJ. The influence of the competition phase and the result of the match on the competitive demands in football 5-a-side for the visually impaired. Int J Perform Anal Sport. 2021;21(1):1-11.

8. Khodja RMI, Hicham B, Mokrani D. The Development of the Physiological Adjustment of Physical Loads and Its Impact on the Circulatory System and the Skills of Football Players. Acta Facultatis Educationis Physicae Universitatis Comenianae. 2019;59(2):193-202.

9. Raya-González J, Nakamura FY, Castillo D, Yanci J, Fanchini M. Determining the relationship between internal load markers and noncontact injuries in young elite soccer players. Int J Sports Physio Perform. 2019;14(4):421-5. 